\title{
Flypaper Effect on Operating Expenditure and Capital Expenditure of the City Government in Indonesia
}

\author{
Endah Purbarini, Gregorius N. Masdjojo \\ Post Graduate Program in Regional Financial, Universitas Stikubank, Semarang \\ Jalan Trilomba Juang No 1 Semarang 50241, Indonesia. Telp. +62-024-8451976 \\ E-mail: endah_budiman@yahoo.co.id, masdjojo@unisbank.ac.id
}

Received: March 2015; Accepted: May 2015

\section{Abstract}

This research analyze the possibility of flypaper effect on Operating Expenditure (OE) and Capital Expenditure (CE) of the City Government in Indonesia. The research also tested the effect of the Original Regional Revenue (ORR) and the General Allocation Fund (GAF) against OE and CE in the period of 2010-2012. Types of data used was the data panel, which is a combination data 2010-2012 time series and cross section 56 city. This research used panel data regression analysis which is estimated by Fixed Effect Model (FEM) and Random Effect Model (REM). The results of this research indicate that the ORR and GAF have positive and significant effect on OE. Furthermore this research find that flypaper effect occurs in OE. But the GAF is not significant to the CE. The ORR have a positive and significant effect on CE. Furthermore this research find that flypaper effect does not occur on CE.

Keywords: the general allocation fund (GAF), the original regional revenue (ORR), operating expenditure (OE), capital expenditure (CE), flypaper effect

JEL Classification: H7, R51

\section{Flypaper Effect pada Belanja Operasi dan Belanja Modal dari Pemerintah Kota di Indonesia}

\begin{abstract}
Abstrak
Penelitian ini menganalisis kemungkinan terjadinya flypaper effect pada Belanja Operasi dan Belanja Modal Pemerintah Kota di Indonesia. Penelitian ini juga menguji pengaruh Pendapatan Asli Daerah (PAD) dan Dana Alokasi Umum (DAU) terhadap Belanja Operasi dan Belanja Modal Pemerintah Kota di Indonesia dalam periode 2010-2012. Jenis data yang digunakan adalah data panel yaitu gabungan data time series 2010-2012 dan cross section 56 kota. Penelitian ini menggunakan analisis regresi data panel dengan metode estimasi Fixed Effect Model (FEM) dan Random Effect Model (REM). Hasil penelitian menunjukkan bahwa PAD dan DAU berpengaruh positif dan signifikan terhadap Belanja Operasi. Selanjutnya ditemukan pula terjadi flypaper effect pada Belanja Operasi. DAU berpengaruh tidak signifikan terhadap Belanja Modal sedangkan PAD berpengaruh positif dan signifikan terhadap Belanja Modal. Dengan demikian tidak terjadi flypaper effect pada Belanja Modal.
\end{abstract}

Kata kunci: dana alokasi umum (DAU), pendapatan asli daerah (PAD), belanja operasi (BO), belanja modal (BM), flypaper effect

Klasifikasi JEL: H7, R51

\section{Pendahuluan}

Salah satu indikator keberhasilan pelaksanaan otonomi daerah adalah meningkatnya kemampuan daerah untuk membiayai sendiri berbagai kebutuhan pembiayaan baik langsung maupun tidak langsung (Mahmudi, 2010 dan Adisasmita, 2011). Hal ini dapat dilihat dari kemampuan meningkatkan perolehan Pendapatan Asli Daerah (PAD) (Rinaldi, 2012). PAD didapatkan 
Avalaible online at http://journals.ums.ac.id

Jurnal Ekonomi Pembangunan, 16 (1), Juni 2015, 75-84

Tabel 1. Kontribusi Dana Transfer dan PAD terhadap Pendapatan Daerah Kabupaten/Kota di Indonesia tahun 2010 - 2012

\begin{tabular}{ccc}
\hline Tahun & $\begin{array}{c}\text { Dana Transfer terhadap } \\
\text { Pendapatan Daerah }\end{array}$ & $\begin{array}{c}\text { PAD terhadap } \\
\text { Pendapatan Daerah }\end{array}$ \\
\hline 2010 & $89,15 \%$ & $7,42 \%$ \\
2011 & $89,00 \%$ & $7,80 \%$ \\
2012 & $87,24 \%$ & $9,75 \%$ \\
\hline
\end{tabular}

Sumber: DJPK, diolah 2014

dari hasil pajak daerah, hasil retribusi daerah, hasil pengelolaan kekayaan daerah yang dipisahkan dan lain -lain PAD yang sah. Semakin baik PAD suatu daerah maka semakin besar pula alokasi belanja modalnya (Ardhani, 2011; Darwanto et al., 2007). Kenyataan yang ada, PAD yang dihasilkan oleh hampir semua kabupaten/kota di Indonesia menunjukkan prosentase yang masih kecil. Tabel 1 memberikan gambaran bahwa dana transfer sangat mendominasi pendapatan daerah Kabupaten / Kota di Indonesia dibandingkan PAD.

Kenyataan lain juga menunjukkan bahwa pertumbuhan PAD dari tahun ke tahun masih sangat kecil dan cenderung berada di bawah pertumbuhan DAU. Gambar 1 menunjukkan fakta tersebut.

Permasalahan yang terjadi saat ini, pemerintah daerah terlalu menggantungkan alokasi DAU untuk membiayai belanja pemerintah daerah tanpa mengoptimalkan potensi yang dimiliki daerah. Di saat alokasi DAU yang diperoleh besar, maka pemerintah daerah akan berusaha agar pada periode berikutnya dana Alokasi Umum diperoleh tetap porsi nominalnya. Menurut Ndadari (2008) proporsi DAU terhadap penerimaan daerah masih yang tertinggi dibandingkan dengan penerimaan daerah yang lain, termasuk PAD. Hal ini dapat dilihat pada tabel 2.

Apabila dibandingkan rata-rata PAD Kota dengan PAD Kabupaten terlihat bahwa ratarata Pemkot lebih besar dari rata-rata Pemkab. Fakta tersebut dapat dilihat pada tabel 3.

Fakta tersebut merupakan persoalan dalam pengelolaan keuangan daerah. Telah banyak peneliti yang melakukan studi tentang penilaian terhadap kemampuan daerah sendiri dibanding bantuan dari pusat yang dilakukan melalui analisis flypaper effect (Richard, 2001; Reinikka, 2004, Choi, 2007; Dahlberg, 2008; Singhal, 2008; Gstoettner, 2010 and Dalle, 2011).

Bagi pemerintah daerah dana perimbangan merupakan salah satu pos pendapatan yang

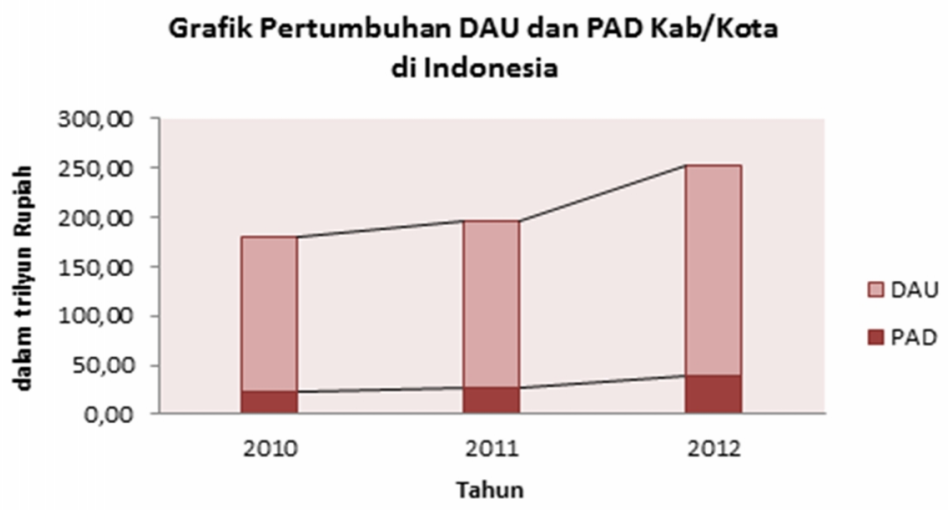

Sumber: DJPK, diolah 2014

Gambar 1. Pertumbuhan DAU dan PAD Kabupaten/Kota di Indonesia tahun 2010 - 2012 
Avalaible online at http://journals.ums.ac.id

Jurnal Ekonomi Pembangunan, 16 (1), Juni 2015, 75-84

Tabel 2. Persentase DAU dan PAD terhadap Pendapatan Daerah Kabupaten/Kota di Indonesia tahun 2010 - 2012

\begin{tabular}{ccc}
\hline Tahun & $\begin{array}{c}\text { Persentase DAU terhadap Pendapatan } \\
\text { Daerah Kabupaten/ Kota di Indonesia }\end{array}$ & $\begin{array}{l}\text { Persentase PAD terhadap Pendapatan } \\
\text { Daerah Kabupaten/Kota di Indonesia }\end{array}$ \\
\hline 2010 & $52,75 \%$ & $7,42 \%$ \\
2011 & $50,22 \%$ & $7,80 \%$ \\
2012 & $53,75 \%$ & $9,75 \%$ \\
\hline
\end{tabular}

Sumber : DJPK, diolah 2014

sangat signifikan. Hal ini nampak pada prakteknya bahwa transfer dari pusat merupakan sumber dana utama bagi pemerintah daerah untuk membiayai keperluan operasional Anggaran Pendapatan dan Belanja Daerah. Ketika penerimaan daerah berasal dari transfer dari pemerintah pusat, maka stimulus yang ditimbulkan berbeda dengan stimulus yang muncul dari pendapatan daerah (terutama pajak daerah). Saat respon (belanja) daerah lebih besar terhadap transfer daripada pendapatan asli daerahnya sendiri, maka disebut flypaper effect (Fausto, 2001; Melo, 2002; Dharmapala, 2012 dan Hines, 1995 dalam Lambut et al, 2013).

Pemberian transfer berakibat pada ketidakefektifan dalam pembiayaan pengeluaran daerah. Fenomena tersebut dikenal dengan flypaper effect yang mengandung pengertian: (1) terjadinya peningkatan pajak dan anggaran belanja pemerintah yang berlebihan, (2) elastisitas pengeluaran terhadap transfer yang lebih tinggi dari pada elastisitas pengeluaran terhadap pajak daerah (Melo, 2002; Gstoettner, 2010; Dalle, 2011 dan Venter, 2007 dalam Rokhaniyah et al , 2011).

Berdasarkan uraian tersebut di atas, maka penelitian ini dirancang untuk menelusuri apakah terjadi Fly Paper Effect melalui Belanja Operasi dan Belanja Modal khususnya bagi pemerintah Kota di Indonesia.

\section{Metode Penelitian}

\subsection{Obyek, Populasi dan Sampel Penelitian}

Obyek penelitian ini adalah Pemerintah Kota di Indonesia yang. Berdasarkan metode purposive sampling, maka jumlah sampel hanya 56 dari 98 Pemerintah Kota di Indonesia yang memenuhi kriteria sebagai berikut: 1) Tidak mengalami perubahan dalam periode 2010 -2012. 2) Ketersediaan data laporan realisasi APBD periode 2010-2012.

\subsection{Model Empirik Penelitian}

Secara teoritis pengaruh variabel dependen terhadap variabel independen dalam penelitian ini dapat dijelaskan dalam model empiris penelitian yang tampak dalam dalam Gambar 3 dan Gambar 4.

Tabel 3. Rata-rata PAD Kabupaten/Kota di Indonesia 2010 - 2012

\begin{tabular}{ccc}
\hline Tahun & $\begin{array}{c}\text { Rata-rata PAD Pemkot di Indonesia } \\
\text { (jutaan Rp) }\end{array}$ & $\begin{array}{c}\text { Rata-rata PAD Pemkab di Indonesia } \\
\text { (jutaan Rp) }\end{array}$ \\
\hline 2010 & 87.337 & 41.819 \\
2011 & 118.035 & 50.994 \\
2012 & 165.875 & 73.307 \\
\hline
\end{tabular}

Sumber : DJPK, diolah 2014. 
Jurnal Ekonomi Pembangunan, 16 (1), Juni 2015, 75-84

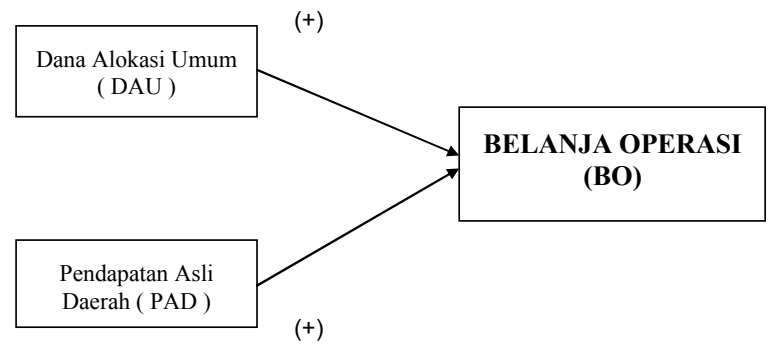

H1: Pengaruh $\mathrm{DAU}_{\text {it }}$ terhadap $\mathrm{BO}_{\text {it }}$ lebih besar daripada pengaruh $\mathrm{PAD}_{\text {it }}$ terhadap $\mathrm{BO}_{\text {it. }}$

Gambar 3. Hubungan DAU dan PAD dengan BM

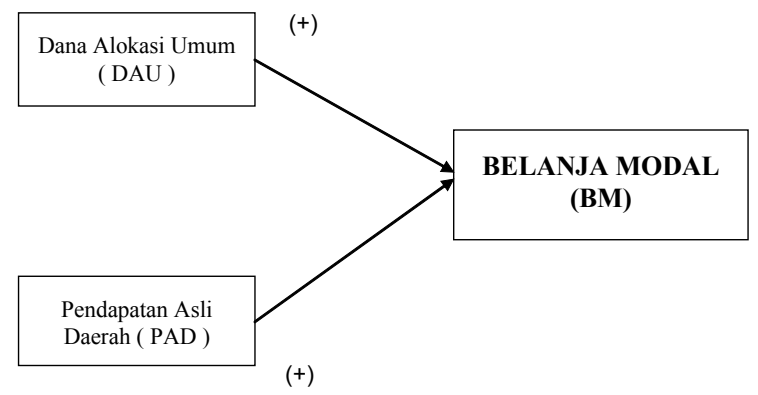

H2: Pengaruh DAUit terhadap BMit lebih besar daripada pengaruh $\mathrm{PAD}_{\text {it }}$ terhadap $\mathrm{BM}_{\mathrm{it}}$.

Gambar 4. Hubungan DAU dan PAD dengan BM

\subsection{Pengembangan Hipotesis}

Beberapa peneliti menemukan respon Pemerintah Daerah berbeda untuk transfer dan pendapatan sendiri (seperti pajak). Artinya ketika penerimaan daerah berasal dari transfer, maka stimulasi atas belanja yang ditimbulkannya berbeda dengan stimulasi yang muncul dari pendapatan daerah (terutama pajak daerah). Ketika respon (belanja) daerah lebih besar terhadap transfer, maka disebut flypaper effect (Oates, 1999 dalam Abdullah et al., 2003).

Lambut, et al. (2013) menyimpulkan bahwa pada 5 (lima) pemerintah daerah di Provinsi Sulawesi Utara ditemukan terjadi Flypaper effect dalam kurun waktu realisasi anggaran 2006-2010. Afrizawati (2012) menemukan bahwa, terjadi Flypaper Effect pada Belanja Daerah di Kabupaten/kota di Sumatera Selatan. Siti Rokhaniyah, et al. (2011) menyimpulkan tidak terjadi flypaper effect pada Belanja Daerah, baik di Jawa maupun luar Jawa karena respon PAD terhadap Belanja Daerah lebih cepat dari pada respon DAU terhadap Belanja Daerah. Kesit Bambang Prakosa (2004 menemukan telah terjadi flypaper effect dalam respon Pemda terhadap DAU dan PAD.

Unun Dian Anggraeni, et al. (2010) menyimpulkan bahwa pengaruh DAU terhadap Belanja Pemda lebih besar daripada pengaruh PAD terhadap Belanja Pemda. Hartati (2009) menyimpulkan bahwa terjadi flypaper effect pada Dana Alokasi Umum (DAU) dan Pendapatan Asli Daerah (PAD) terhadap Belanja Daerah pada kabupaten/kota di Propinsi Jawa Tengah. Namun berdasarkan tulisan Darby et al. (2004) definisi Flypaper Effect dapat pula dijelaskan berdasarkan elastisitas atau tingkat responsif prosentase perubahan pada pengeluaran pemerintah karena perubahan dana transfer dari pusat.

Berdasarkan pendapat-pendapat tersebut di atas, maka dalam tulisan ini ditawarkan konsep lain berkaitan dengan terjadinya flypaper effect, dengan melihat responsif pengeluaran pemerintah daerah terhadap perubahan transfer dari pemerintah pusat. Apabila koefisien transfer tidak bersyarat (Unconditional grants) lebih dari 1, maka terjadi flypaper effect. Namun apabila kurang atau sama dengan 1, maka tidak terjadi flypaper effect.

Maka hipotesis untuk menguji flypaper effect Pemerintah Kota di Indonesia dalam penelitian ini adalah: (1) Apabila Responsif perubahan BO berlipat ganda terhadap perubahan DAU, maka terjadi flypaper effect, (2) Apabila Responsif perubahan BM berlipat ganda terhadap perubahan DAU, maka terjadi flypaper effect.

\subsection{Metode Analisis Data}

Metode analisis yang digunakan dalam penelitian ini adalah metode analisis regresi berganda data panel (panel data regression). Berikut persamaan-persamaan regresi data panel yang digunakan dalam pengujian hipotesis 1 dan 2 : 
Jurnal Ekonomi Pembangunan, 16 (1), Juni 2015, 75-84

$\operatorname{LogBO}_{i t}=\alpha+B_{1} \operatorname{LogDAU} U_{i t}+B_{2} \operatorname{LogPAD} D_{i t}+e_{i t}(1)$

$\operatorname{LogBM}_{i t}=\alpha+B_{1} \operatorname{LogDAU}_{\mathrm{it}}+B_{2} \operatorname{LogPAD} \mathrm{D}_{\mathrm{it}}+\mathrm{e}_{\mathrm{it}}(2)$

di mana $\log \boldsymbol{B} \boldsymbol{O}_{i t}$ adalah logaritma Belanja Operasi dan $\mathbf{L o g B M}$ it adalah logaritma Belanja Modal, $\boldsymbol{\alpha}$ konstanta, $\boldsymbol{\beta}_{\boldsymbol{1}} \boldsymbol{\beta}_{\mathbf{2}}$ koefisien regresi, $\log D \boldsymbol{A} U_{t}$ adalah logaritma DAU, $\log P A D_{t}$ adalah logaritma PAD, dan e error term.

Untuk mengestimasi model tersebut di atas menurut Gujarati (2006), akan menggunakan Fixed Effect Model (FEM) atau Random Effect Model (REM). Pemilihan model mana yang akan digunakan ditentukan oleh hasil uji Hausman.

\section{Hasil dan Pembahasan}

\subsection{Estimasi Generalized Least Square Regresi 1}

Berdasarkan hasil estimasi dengan metode GLS (Tabel 4 dalam lampiran), Random Effects Model (REM) menunjukkan hasil yang lebih baik dibandingkan dengan Fixed Effects Model (FEM). Hal ini bisa dilihat dari nilai koefisien regresi dari masing-masing variabel independennya dan secara statistik berpengaruh signifikan terhadap Belanja Operasi Pemerintah Kota di Indonesia. Di samping itu nilai $A d$ justed R-squared dan nilai Durbin-Watsonnya yang lebih baik pada Random Effects Model (REM) dibandingkan nilai Fixed Effects Model (FEM).

\subsection{Estimasi Generalized Least Square Regresi 2}

Berdasarkan hasil estimasi dengan metode GLS (Tabel 5 dalam Lampiran), Random Effects Model (REM) menunjukkan hasil yang lebih baik dibandingkan dengan Fixed Effects Model (FEM). Hal ini bisa dilihat dari nilai koefisien regresi dari masing-masing variabel independennya dan secara statistik berpengaruh signifikan terhadap Belanja Modal Pemerintah Kota di Indonesia. Di samping itu nilai Adjusted Rsquared dan nilai Durbin-Watsonnya yang lebih baik pada Random Effects Model (REM) dibandingkan nilai Fixed Effects Model (FEM).

\subsection{Hasil Uji Haussman Persamaan Regresi 1}

Tabel 6. Hasil Uji Haussman Persamaan Regresi 1

Correlated Random Effects - Hausman Tests

Pool : POOL1

Test period random effects

\begin{tabular}{lccc}
\hline Test Summary & $\begin{array}{l}\text { Chi-Sq } \\
\text { Statistic }\end{array}$ & $\begin{array}{l}\text { Chi-Sq } \\
\text { d.f. }\end{array}$ & Prob \\
\hline Period random & 0,093269 & 2 & 0,9544
\end{tabular}

Sumber: Olahan peneliti, Maret 2014

Berdasarkan uji Haussman yang dilakukan diperoleh nilai chi-square statistik sebesar 0,093269 dengan probabilitas 0,9544 dan d.f 2, dengan menggunakan chi-square tabel diperoleh nilai sebesar 124,342. Hasil tes menunjukkan bahwa chi-square statistik lebih kecil dari tabel chi-square, probabilitas lebih besar dari 0,05, maka dapat disimpulkan bahwa $\mathrm{H} 1$ ditolak, berarti model yang tepat adalah REM.

\subsection{Hasil Uji Haussman Persamaan Regresi 2}

Tabel 7. Hasil Uji Haussman Persamaan Regresi 2

Correlated Random Effects - Hausman Tests

Pool : POOL2

Test period random effects

\begin{tabular}{cccc}
\hline Test Summary & $\begin{array}{c}\text { Chi-Sq } \\
\text { Statistic }\end{array}$ & $\begin{array}{c}\text { Chi-Sq } \\
\text { d.f. }\end{array}$ & Prob \\
\hline Period random & 1,943798 & 2 & 0,3784
\end{tabular}

Sumber: Olahan peneliti, Maret 2014

Berdasarkan uji Hausman yang dilakukan diperoleh nilai chi-square statistik sebesar 1,943798 dengan probabilitas 0,3784 dan d.f 2, dengan menggunakan tabel chi-square diperoleh nilai sebesar 124,342. Hasil tes menunjukkan bahwa chi-square statistik lebih kecil dari tabel chi-square, probabilitas lebih besar dari 0,05, maka dapat disimpulkan bahwa $\mathrm{H}_{1}$ ditolak, berarti model yang tepat adalah REM. 
Jurnal Ekonomi Pembangunan, 16 (1), Juni 2015, 75-84

Tabel 8. Hasil Estimasi Random Effects Model (REM) Persamaan Regresi 1

Dependent Variable : BO?

Method: Pooled EGLS (period random effects)

\begin{tabular}{lccc}
\hline \multicolumn{1}{r}{ Independent Variable } & Coefficient & t-Statistic & Prob \\
\hline C & 7,223280 & 17,36686 & 0,0000 \\
DAU? & 0,119304 & 3,216127 & 0,0016 \\
PAD? & 0,399692 & 25,81597 & 0,0000 \\
\hline
\end{tabular}

Sumber: Olahan peneliti, Maret 2014

\subsection{Pengujian Hipotesis}

\subsubsection{Hasil Uji Hipotesis 1}

Berdasarkan Tabel 8 diketahui hasil pengujian Hipotesis 1 yaitu:

1) Nilai t-statistik $>$ dari t-tabel atau nilai probabilitas (sig) $<0,05$, maka dapat disimpulkan bahwa Dana Alokasi Umum (DAU) berpengaruh positif dan signifikan terhadap Belanja Operasi.

2) Nilai t-statistik $>$ t-tabel atau nilai probabilitas (sig) $<0,05$, maka dapat disimpulkan bahwa Pendapatan Asli Daerah (PAD) berpengaruh positif dan signifikan terhadap Belanja Operasi.

3) Koefisien DAU 0,119304, artinya kenaikan DAU sebesar 1\% akan menaikkan Belanja Operasi sebesar 11,93\%. Berdasarkan ketentuan kon Flypaper Effect, maka kondisi tersebut di atas mengindikasikan adanya Flypaper Effect terhadap Belanja Operasi.

\subsubsection{Hasil Uji Hipotesis 2}

Berdasarkan Tabel 9 diketahui bahwa:

1) Nilai t-statistik < t-tabel atau nilai probabilitas (sig) $>0,05$, maka dapat disimpulkan bah- wa Dana Alokasi Umum (DAU) tidak berpengaruh signifikan terhadap Belanja Modal.

2) Nilai t-statistik $>$ t-tabel atau probabilitas (sig) $<0,05$, maka dapat disimpulkan bahwa Pendapatan Asli Daerah (PAD) berpengaruh positif dan signifikan terhadap Belanja Modal.

3) Melihat pengaruh DAU terhadap Belanja Modal yang tidak signifikan, maka dapat disimpulkan tidak terjadi Flypaper Effect terhadap Belanja Modal.

\subsection{Pembahasan}

\subsubsection{Tingkat Responsif perubahan BO terhadap perubahan DAU}

Berdasarkan hasil estimasi regresi diperoleh persamaan sebagai berikut:

$$
\begin{aligned}
\log Y_{i t}= & 7,223280+0,119304 \operatorname{LogDAU} U_{i t}+ \\
& 0,399692 \log P D_{i t}
\end{aligned}
$$

Dana Alokasi Umum mempunyai pengaruh positif dan signifikan terhadap Belanja Operasi dan koefisiennya sebesar 0,119304 artinya apabila DAU 56 pemerintah Kota di Indonesia

Tabel 9. Hasil Estimasi Random Effects Model (REM) Regresi 2

Dependent Variable : BM

Method : Pooled EGLS (Period random effects)

\begin{tabular}{lrrr}
\hline \multicolumn{1}{r}{ Independent Variable } & Coefficient & t-Statistic & Prob \\
\hline C & 8,783431 & 9,182279 & 0,0000 \\
DAU & $-0,068546$ & $-0,803456$ & 0,4229 \\
PAD & 0,342991 & 9,632645 & 0,0000 \\
\hline
\end{tabular}

Sumber: Olahan peneliti, Maret 2014 


\section{Jurnal Ekonomi Pembangunan, 16 (1), Juni 2015, 75-84}

naik sebesar 1\% akan menaikkan Belanja Operasi 56 pemerintah Kota di Indonesia sebesar $11,93 \%$ (ceteris paribus). Di mana kenaikan DAU sebesar 1\% akan menaikkan Belanja Operasi sebesar 11,93\%. Melihat dampak kenaikan DAU terhadap Belanja Operasi yang lebih dari $1 \%$ dan signifikan, maka dapat disimpulkan telah terjadi Flypaper Effect terhadap Belanja Operasi.

Pendapatan Asli Daerah mempunyai pengaruh positif dan signifikan terhadap Belanja Operasi dan koefisiennya sebesar 0,399692 artinya apabila PAD 56 pemerintah Kota di Indonesia naik sebesar 1\% akan menaikkan Belanja Operasi 56 pemerintah Kota di Indonesia sebesar 39,96\% (cateris paribus) .

Hasil tersebut sejalan dengan penelitian Lambut et al. (2013), Afrizawati (2012), Anggraeni et al. (2010), Hartati (2009) dan Prakosa (2004) yang menyatakan bahwa telah terjadi flypaper effect pada belanja daerah. Namun hasil ini berbeda dengan yang dilakukan oleh Rokhaniyah et al. (2011).

\subsubsection{Tingkat Responsif perubahan BM terhadap perubahan DAU}

Berdasarkan hasil estimasi regresi data panel diperoleh hasil sebagai berikut:

$$
\begin{aligned}
\operatorname{LogBM}_{i t}= & 8,783431-0,068546 \operatorname{LogDAU}_{\mathrm{it}}+ \\
& \text { 0,342991 LogPAD }
\end{aligned}
$$

Hasil estimasi di atas memberikan informasi bahwa Dana Alokasi Umum mempunyai pengaruh tidak signifikan terhadap Belanja Modal.

Pendapatan Asli Daerah mempunyai pengaruh positif dan signifikan terhadap Belanja Modal dan koefisiennya sebesar 0,342991 artinya apabila PAD 56 pemerintah Kota di Indonesia naik sebesar 1\% akan menaikkan Belanja Modal 56 pemerintah Kota di Indonesia sebesar $34,29 \%$ (cateris paribus). Juga berarti PAD mempunyai pengaruh terhadap Belanja Modal 56 pemerintah Kota di Indonesia. Semakin tinggi besaran PAD maka Belanja Modal akan semakin tinggi pula.
Berdasarkan hasil analisis regresi linier berganda yang telah disajikan, tampak bahwa Dana Alokasi Umum mempunyai pengaruh tidak signifikan terhadap Belanja Modal, maka dapat disimpulkan tidak terjadi Flypaper Effect terhadap Belanja Modal.

Hasil tersebut sejalan dengan penelitian Rokhaniyah et al. (2011) yang menyatakan bahwa tidak terjadi flypaper effect pada belanja daerah pemerintah provinsi di Indonesia. Namun hasil tersebut berbeda dengan yang dilakukan oleh Lambut et al. (2013), Afrizawati (2012), Anggraeni et al. (2010), Hartati (2009) dan Prakosa (2004).

\subsection{Interpretasi Estimasi Random Effect Model (REM)}

\subsubsection{Persamaan Regresi 1}

Hasil estimasi Persamaan Regresi 1 dengan menggunakan Random Effect Model, diperoleh koefisien Random Effect yang berbeda antar 56 pemerintah Kota di Indonesia di setiap tahunnya, dengan hasil sebagai berikut:

Tabel 10. Koefisien Random Effect Model (REM) Persamaan Regresi 1

\begin{tabular}{cc}
\hline Random Effects (Period) & Coefficient \\
\hline $2010-\mathrm{C}$ & $-3,15 \mathrm{E}-13$ \\
$2011-\mathrm{C}$ & $-2,04 \mathrm{E}-13$ \\
$2012-\mathrm{C}$ & $5,19 \mathrm{E}-13$ \\
\hline
\end{tabular}

Sumber: Olahan peneliti, Maret 2014

Tabel 10 memperlihatkan bahwa masingmasing Pemerintah Kota memiliki tingkat koefisien random effect yang berbeda untuk tiap tahunnya. Keadaan tersebut dapat dijelaskan bahwa variabel PAD dan DAU memiliki tingkat pengaruh yang berbeda terhadap Belanja Operasi pada tiap-tiap Pemerintah Kota di Indonesia di tiap-tiap tahunnya. Koefisien random effect tersebut menunjukkan bahwa bila terdapat perubahan satu persen pada DAU dan PAD 


\section{Jurnal Ekonomi Pembangunan, 16 (1), Juni 2015, 75-84}

pada antar daerah maupun antarwaktu di 56 Pemerintah Kota di Indonesia maka Pemerintah Kota tersebut akan mendapatkan pengaruh individu terhadap Belanja Operasi sebesar koefisien random effectnya. Tahun 2010, koefisien random effect terendah artinya jika terdapat perubahan $1 \%$ pada DAU dan PAD pada antardaerah maupun antarwaktu di Pemerintah Kota di Indonesia, maka pada tiap Pemerintah Kota akan mendapatkan pengaruh individu terhadap Belanja Operasi sebesar:

$-0,0000000000315 \%$ dan tertinggi pada tahun 2012 artinya jika terdapat perubahan 1\% pada DAU dan PAD pada antardaerah maupun antar waktu di Pemerintah Kota di Indonesia, maka pada tiap Pemerintah Kota akan mendapatkan pengaruh individu terhadap Belanja Operasi sebesar 0,0000000000519\%. Hal ini sebagai efek perubahan waktu.

\subsubsection{Persamaan Regresi 2}

Tabel 11 memperlihatkan masing-masing Pemerintah Kota memiliki tingkat koefisien random effect yang berbeda untuk tiap tahunnya. Keadaan tersebut dapat dijelaskan bahwa variabel PAD dan DAU memiliki tingkat pengaruh yang berbeda terhadap Belanja Modal pada tiap-tiap Pemerintah Kota di Indonesia di tiaptiap tahunnya.

Tabel 11. Koefisien Random Effect Model (REM) Persamaan Regresi 2

\begin{tabular}{cc}
\hline Random Effects (Cross) & Coefficient \\
\hline $2010-\mathrm{C}$ & $-9,52 \mathrm{E}-12$ \\
$2011-\mathrm{C}$ & $3,68 \mathrm{E}-12$ \\
$2012-\mathrm{C}$ & $5,84 \mathrm{E}-12$ \\
\hline
\end{tabular}

Sumber: Olahan peneliti, Maret 2014

Koefisien random effect tersebut menunjukkan bahwa bila terdapat perubahan satu persen pada DAU dan PAD pada antardaerah maupun antar waktu di 56 Pemerintah Kota di Indonesia maka Pemerintah Kota tersebut akan mendapatkan pengaruh individu terhadap Belanja
Modal sebesar koefisien random effectnya. Tahun 2010, koefisien random effect terendah artinya jika terdapat perubahan $1 \%$ pada DAU dan PAD pada antardaerah maupun antarwaktu di Pemerintah Kota di Indonesia, maka pada tiap Pemerintah Kota akan mendapatkan pengaruh individu terhadap Belanja Modal sebesar: -0,000000000952\% dan tertinggi pada tahun 2012 artinya jika terdapat perubahan 1\% pada DAU dan PAD pada antardaerah maupun antarwaktu di Pemerintah Kota di Indonesia, maka pada tiap Pemerintah Kota akan mendapatkan pengaruh individu terhadap Belanja Operasi sebesar: 0,000000000584\%. Hal ini sebagai efek perubahan waktu.

\section{Simpulan}

Penelitian ini menyimpulkan beberapa hal yaitu: Pertama; Flypaper effect terjadi pada Belanja Operasi pemerintah kota di Indonesia. Dana Alokasi Umum (DAU) dan Pendapatan Asli Daerah (PAD) masing-masing berpengaruh positif dan signifikan terhadap Belanja Operasi. Kedua; Flypaper effect tidak terjadi pada Belanja Modal pemerintah kota di Indonesia. Dana Alokasi Umum (DAU) berpengaruh tidak signifikan dan Pendapatan Asli Daerah (PAD) berpengaruh positif signifikan terhadap Belanja Modal.

Penelitian ini memiliki beberapa keterbatasan yaitu: Pertama; Sampel yang digunakan hanya 56 Pemerintah Kota di Indonesia. Penelitian berikutnya diharapkan dapat memasukkan seluruh Pemerintah Kota dan juga Pemerintah Kabupaten di Indonesia. Kedua; Periode penelitian juga relatif pendek yaitu hanya tiga tahun penelitian. Diharapkan pada penelitian selanjutnya periode penelitian dapat lebih panjang.

\section{Daftar Pustaka}

Abdullah, A. H. 2003. Pengaruh dana alokasi umum (DAU) dan pendapatan asli daerah (PAD) terhadap belanja pemerintah daerah: studi kasus kabupaten/kota di Jawa dan Bali. Simposium Nasional Akuntansi VI, Yogyakarta, 1140-1159. 


\section{Jurnal Ekonomi Pembangunan, 16 (1), Juni 2015, 75-84}

Adisasmita, R. 2011. Pembiayaan pembangunan daerah. Yogyakarta: Graha Ilmu.

Afrizawati. 2012. Analisis flypaper effect pada belanja daerah kabupaten/kota di Sumatera Selatan. Jurnal Ekonomi dan Informasi Akuntansi (JENIUS), Vol. 2, No.1 .

Sekretariat Negara. 2006. Peraturan menteri dalam negeri (Permendagri) nomor 13 tahun 2006. Jakarta: Sekretariat Negara.

Sekretariat Negara. 2008. Undang-Undang Republik Indonesia Nomor 12 tahun 2008. Jakarta: Sekretariat Negara.

Ardhani, P. 2011. Pengaruh pertumbuhan ekonomi, pendapatan asli daerah, dana alokasi umum dan dana alokasi khusus terhadap pengalokasian anggaran belanja modal (studi pada pemerintah kabupaten/kota di Jawa Tengah. Semarang: unpublished skripsi Fakultas Ekonomi Universitas Diponegoro.

Ariefianto, M. D. 2012. Ekonometrika esensi dan aplikasi dengan eviews. Jakarta: Penerbit Erlangga.

Choi, James J., David Laibson and Brigitte C. Madrian. 2007. Mental accounting in portofolio choice: evidence from a flypaper effect. Working Paper 13656 .

Dahlberg, Matz, Eva Mörk, Jorn Rattsø \& Hanna Agren 2008. Using a discontinuous grant rule to identify the effect of grants on local taxes and spending. Journal of Public Economics, Vol.92 (December), 2320-2335.

Dharmapala, D., \& Khanna, V. 2012. Corporate governance, enforcement and firm: evidence from India. Journal of Law, Economics and Organization, April 7 .

Fausto, D. 2001. Issues of Public finance theory in attilio da empoli's scientific work. Journal of Economic Studies, 28(4), 284298 .

Ghozali, I. 2011. Aplikasi analisis multivariate dengan program IBM SPSS 19. edisi 5. Semarang: Badan Penerbit Universitas Diponegoro.
Gstoettner, M \& Jensen, A 2010. Aid and public finance: a missing link? Atlantic Economic Journal, 38(2) , 217-235.

Halim, A. 2001. Anggaran daerah dan fiscal stress (sebuah studi kasus pada anggaran daerah provinsi di Indonesia. Jurnal Ekonomi dan Bisnis Indonesia, Vol. 16 .

Hartati. 2009. Flypaper effect pada dana alokasi umum (DAU) dan pendapatan asli daerah (PAD) terhadap belanja daerah serta dampaknya terhadap kinerja keuangan pada kabupaten/kota di Provinsi Jawa Tengah. Surakarta: Unpublished Tesis, program pascasarjana fakultas ekonomi akuntansi Universitas Sebelas Maret .

Julia Darby, A. M. 2004. Fiscal federalism, fiscal consolidations and cuts in central government grants: evidence from an event study. working paper (14 March 2004), 1-29.

Kuncoro, H. 2004. Pengaruh transfer antar pemerintah pada kinerja fiskal pemerintah daerah kota dan kabupaten di Indonesia. Jurnal Ekonomi Pembangunan Univeristas Gadjah Mada, Vol.9, No.1 .

Lambut, Adventinus Kristanto, S. S. 2013. Analisis flypaper effect pada pemerintah daerah di Provinsi Sulawesi Utara. Jurnal Riset Akuntansi dan Auditing, Vol. 4, No.1.

Mahmudi. 2010. Analisis laporan keuangan pemerintah daerah. Yogyakarta: UPP STIM YKPN .

M. Dahlberg, M. E. 2008. Using a discontinuous grant rule to identify the effect of local taxes and spending. Journal of Public Economics, 92 , 2320-2335.

Melo, L. 2002. The flypaper effect under different institutional contexts: The Colombian Case. Public Choice, 111 (3-4) , 317-345.

Nogare, Dalle C. \& Galizzi, M. 2011. The political economy of cultural spending evidence from Italian Cities. Journal of Cultural Economics, 35 (3) , 203-231. 


\section{Jurnal Ekonomi Pembangunan, 16 (1), Juni 2015, 75-84}

Prakosa, K. B. 2004. Analisis pengaruh dana alokasi umum (DAU) dan pendapatan asli daerah (PAD) terhadap prediksi belanja daerah (studi empirik di wilayah Provinsi Jawa Tengah dan DIY). JAAI, Vol. 8, No.2

Rahman, A. D. 2007. Flypaper effect pada dana alokasi umum (DAU) dan pendapatan asli daerah (PAD) terhadap belanja daerah pada kabupaten/kota di Indonesia. JAAI, Vol. 11, No.1 .

Reinikka, Ritva and Jakob Svensson. 2004. local capture: evidence from a central government transfer in Uganda. Quarterly Journal of Economics, Vol. 93 (May),6, 562-587.

Richard, M. B. 2001. Public finance in a democratic society, volume iii. The foundations of taxation and expenditure. National Tax Journal, 54(1), 175-182.

Rinaldi, U. 2012. Kemandirian keuangan dalam pelaksanaan otonomi daerah. Jurnal EKSOS, Vol. 8, No.2 .
Rokhaniyah, M. R. 2011. Analisis flypaper effect pada belanja pemerintah kota dan kabupaten di indonesia tahun 2006-2008. 100 Fokus Ekonomi (FE), Vol.10, No. 2, 1-15.

Singhal, Monica. 2008. Special interest groups and allocation of public funds. Journal of Public Economics, Vol. 92 (April) , 548654.

Winarno, W. W. 2011. Analisis ekonometrika dan statistika dengan Eviews. Edisi 3. Yogyakarta: UPP STIM YKPN.

Wooldridge, J.M. 2010. Econometric analysis of cross section and panel data. Cambridge: MIT Press.

Worthington, A. C., \& Dollery, B. E. 1999. fiscal illusion and the Australian local government grants process: how sticky is the flypaper effect? Public Choice, 99(1-2), 113.

\section{Lampiran}

Tabel 4. Estimasi Generalized Least Square Regresi 1

Variabel Dependen : BO

\begin{tabular}{lllll}
\hline & FEM & & REM \\
Variabel Independen & Coefficient & Prob & Coefficient & Prob \\
\hline DAU? & 0,116631 & 0,0027 & 0,119304 & 0,0016 \\
PAD? & 0,399519 & 0,0000 & 0,399692 & 0,0000 \\
R-squared & 0,858470 & & 0,858389 & \\
Adjusted R-squared & 0,854997 & & 0,856673 & \\
Durbin-Watson stat & 0,161324 & & 0,163816 & \\
\hline
\end{tabular}

Sumber: Olahan peneliti, Maret 2014

Tabel 5. Hasil Estimasi Generalized Least Square Persamaan Regresi 2

Variabel Dependen : BM

\begin{tabular}{|c|c|c|c|c|}
\hline & FEM & & REM & \\
\hline Variabel Independen & Coefficient & Prob & Coefficient & Prob \\
\hline DAU? & $-0,098282$ & 0,2668 & $-0,068546$ & 0,4229 \\
\hline PAD? & 0,340698 & 0,0000 & 0,342991 & 0,0000 \\
\hline R-squared & 0,411891 & & 0,404878 & \\
\hline Adjusted R-squared & 0,397459 & & 0,397665 & \\
\hline Durbin-Watson stat & 0,659971 & & 0,669338 & \\
\hline
\end{tabular}

Sumber: Olahan peneliti, Maret 2014 